\title{
A Legal Punisment by Judgement in Prosecuting Minor Commited of Criminal Act of Murdering
}

\section{Herlina Panggabean}

\author{
E-mail: linagabe53@gmail.com
}

\begin{abstract}
This research was conducted by statutory and case approach method. The purpose of this study is to find out "How the legal analysis of sentencing by judges in prosecuting murder which is committed by minors in court.Based on the result of the analysis, or as the answer to the above problem is that in the case of the Court which was decided by the Panel of Judges namely Article 340 and Article 351 (2) with the punishment of 20 (twenty) years imprisonment. In the case of applying, the law applied by the panel of judges is appropriate based on article 26 (1) number 2 letter a, Law. No. 3 Year 1997 on Juvenile Justice, at the minimum half of adult punishment or 10 (ten) years imprisonment.
\end{abstract}

Keyword-Crime, Killing, Child.

\section{INTRODUCTION}

The development of children delinquency recently is very high. Children's misbehavior creates anxiety within the community and is concerned and highlighted by the mass media and government, in which the problem of violence occurs resulting in a devastating effect on the future of life and education in the country. The crimes committed by children at the present time draw attention from the government in performing special handling. Through the approach and extension conducted by the government, it is expected to reduce criminal acts in the community for the comfort and public stability.Murder is defined as a deliberate and illegal killing of a person. This resulted, the victim suffered of stabbing injuries, while the eye witnesswas woundedon the left hand due to the fending off the defendant's actions.On the verdict, the Panel of Judges sentenced the accused to imprisonment for eight years which has been fully deducted from the period of his detention. Internal factors that influence the background of the occurrence of this murder are: (1) The existence of social gaps against the fellow workers in the workplace; (2) There is a sense of envy and resentment that is affected by the abusive and unpleasant treatment of fellow workers; (3) The existence of fellow workers' dispute and lack of good communication at work.
External factors that influence the background of the murder are: (1) economic factor is one of the factors that affects the children to commit a criminal act, triggered by the inability of the parents to meet the needs of the children which encouraged children to commit criminal acts; (2) Environmental factors is one of the main determinants of personal formation of children as the development of maturation process; (3) The association factor is one of the supporting factors of children in getting the quality of education and maturity of mindset, both personality and friendship.The purpose of the punishment contains elements such as: (1) Humanity, in the sense that the punishment upholds one's dignity; (2) Educative, in the sense that punishment is able to make people fully aware of the actions done and cause him to have a positive attitude of the soul for the crime prevention; (3) Justice, in the sense that the punishment is perceived as fair (whether by the convict or by the victim or the community).The inclusion of threats of penalty or sanction accompanying the presence of the regulation is necessary to support the regulations imposed on criminal acts, in the hope that they will not repeat the act in addition to the same acts and not being imitated by others. The criminal psychological view of murder that an act of evil is placed on a person's soul and his conduct so as to commit perverse acts contrary to the norms prevailing in society. If viewed in terms of juridical "Murder" is defined as forms of behavior that is contrary to moral humanitarian and harmful to society and its nature violates law and Criminal Law.Criminal acts committed by a person are divided into two groups that can not and can not be accounted for. Against actions that cannot be accounted, itcannot be sentenced to criminal. Against the less reliable, the penalty can be reduced or charged. Criminal is a reaction to the offense that deliberately imposed by the state on the maker of the offense.The penalty system for minors should include legal protection for children. In which, a child is an immature individual, incapable of acting in law. Therefore, it is needed various role of government or society in understanding legal problem experienced by a child.The function of criminal justice in children is necessary for balanced law enforcement 
on each case and child's independence. However, the legal system can function optimally if it is updated with a system appropriate to the conditions of the society.The judge's duty of giving his judgment must be objective. In carrying out their duties, it must be firm and responsible for action when making the right decision. Judge's consideration in imposing criminal penalties is very important, because it is important for the future of a child as the nation's next generation and human resource for national development. In bringing a criminal verdict to the defendant, the judge must be able to consider the willingness of the parents to care for the child, because the willingness of the parents is crucial in controlling the attitude of the child not to commit another criminal act.Efforts and the prevention of crime of murder committed by the child can be executed appropriately if based on the role of the government, whether in conducting coaching, supervision, and legal protection.The research problem identification is: the basis of judges' consideration in prosecuting murder and severe maltreatment perpetrated by minors, with the limitation of the problem is; to know the basis of the judge's consideration in considering the punishment of the child, as well as to know the legal efforts and protection of the rights of the child in prison. For Legal Science, it is as a contribution of thought for students / academic students in developing the science inside or outside the community as well as providing the right solution in murder problems. For the public, is to know the accountability of criminal behavior of murder crime.

\section{THEORETICAL FRAMEWORK}

\section{The Crime Definition}

The definition of a criminal offense is derived from the Dutch term in the Criminal Code, namely "StrafbaarFeit" all elements of unlawful acts that violate the law by a person and can be accounted for. Some expert of jurists try to interpret the meaning and the terms as the appropriateness and the principles of law. ProdjodikoroWiryono, formulates that: Criminal act is a criminal act that the perpetrator may be subject to criminal penalties in accordance with applicable regulations. Simons, formulates that: Criminal acts are an unlawful act that has been deliberately committed by a person who can be held accountable for his actions, expressed as punishable. Moeljatno, formulates that: Criminal acts are all acts that are prohibited by law and can be punishable by criminal punishment to persons violating them. According to Moeljatno, Crime is an act that is prohibited by a rule of law, which prohibition is accompanied by a particular criminal threat, for anyone who violates the prohibition. The elements of the criminal act are:
(1) The act that the action is prohibited (human actions in an event caused by the behavior of people). The prohibition is directed at his actions and his criminal threat is directed against his person. (2) Prohibited restrictions aimed at his actions and criminal penalties aimed at those who commit his actions. (3) The criminal penalty is the imposition of a punishment in accordance with the actions of that person.

\section{The Definition of Murder}

The term of a criminal act of murder is defined as one of the unlawful acts related to intentional or wrongly done by a person and can be accounted for. Crimes against life in the Criminal Code can be distinguished or grouped on two grounds, namely: (1) Crimes against life intentionally, contained in Chapter XIX of the Criminal Code in Articles 338 to 350. (2) Crimes against life which are not intentionally committed (CulposeMisdrihven), contained in Chapter XXI (Special Article 359).Crimes against life committed deliberately (murder) in basic form, published in Article 338 which formulation is:Anyone who deliberately deprives the life of another person is convicted of a penalty with a maximum imprisonment of 15 (fifteen) years. In this aggravated formation, there are two kinds of criminal offenses at once, the one being ordinary murdering in basic form (Article 338) and the other is a crime other than murder. The crime must happen, not the test. If the murder has occurred, but other crimes that have not happened, then the crimes that have been set in Article 339 it does not happen. In the act of encouragement, the initiative to commit suicide is not from the suicide person but from someone else who pushes. In contrast to the deeds of helping and providing the means, because in this act, the initiative for suicide comes from the victim himself. In both these acts there is no influence (inner) whatsoever on the formation of the will for the victim to commit the suicide.

\section{The Development of the Rights of the Child and its Law in the Criminal Justice Process}

The development of children's rights in criminal justice is very important in order to promote and realize legal protection for children. Begin by looking at the mental, physical, social, economic aspects to find out the problems that arise from the pressure or the environment. In this case, the participation of government and parents is needed through the process of proper development and dedication and the noble values of the nation. This can be realized by compiling social data about the child's personality, family, social and economic conditions. Then the pattern of coping with each child and the situation is private.The implementation of rights and obligations for children who commit crimes need to get help and protection to be balanced 
and humane. The obligation of the child should always be considered in accordance with the situation, condition, physical, and social circumstances in order to avoid the implementation of law by an improper judge to children in conflict with the law. The following are rights that need to be fought in the process of the Criminal Court and the matters that the Judge must consider include: (a) Rights are required as unproven; (b) The right of protection from harmful acts, causing mental, physical, and social suffering; (c) The right to obtain counsel from the legal counsel; (d) The right to have transport facilities and counseling in participating counseling, in facilitating the examination; (e) The right to express an opinion; (f) The right to obtain a humane coaching according to Pancasila and the act 1945 and correctional ideas. (g) The right to be in contact with parents and their families.Some of the supporting factors in the efforts to develop the rights of children in criminal justice are: The rationale that supports Pancasila, the 1945 Constitution. The outline of the State's direction of religion, the positive social values of the child, the norm (Declaration of child rights, Child Welfare Act).The growing awareness that children's problems are a national issue that must be addressed as early as possible together.

Counseling, coaching, education and teaching on children including the development of the Child Protection Law courses, child protection efforts concerning the interests of the child; The government together with the community is expanding real efforts in providing facilities for child protection. Some of the constraining factors in the efforts to develop the rights of children in criminal justice are: Lack of proper understanding of the coaching, supervision and prevention efforts that constitute the realization of child protection efforts; Lack of legal belief that children's issues are a national problem that must be handled together as a national responsibility.

\section{The Factors Cause Children in Conflict with the Law}

Factors causing children to deal with the law (1) poverty, This factor is a structural problem that until now there is no proper recipe to fix it. In which, the state can not create enough jobs and decent income for parents who have many children then, the children become drop out. Because the education of the child is low and the child is looking for an important job that can earn money and then can meet the needs of his life. Not being able to resist the consumptive appetite and lack of money on the other hand sometimes make the child become 'dark eyes' to commit a criminal act such as theft, robbery even killing to get the goods or needs he wants. (2) Family Environment, All child problems come from family problems. When parents educate children too hard to make a beating so that between children and parents are hostile to each other.Frequently the child came to the conclusion that he is no longer loved. In addition, there is also a parental ignorance of the fate of his son, so that soon let the child mingle with people whose behavior diverges. There is no control and no affection parent who encourages children since childhood is used to wandering and join their friends who have grown up. This is where the child begins to learn the courage to commit an unlawful act.

\section{The Role of the Law Enforcement Officials}

The system of criminal imprisonment on the children's case and the application of the law by the judge of punishment sanction is divided into two kinds of crime and action. Criminal is divided into two kinds, namely: principal criminal and additional criminal. Criminal Penalty is imprisonment, fine, or criminal supervision. Additional criminal punishment may include the expropriation of certain goods or payment of indemnity, whereas the action is: return to the parent guardian, or foster parent, submit to the state for education, coaching and work training. With regard to the sanction of punishment, the judge shall not impose the accumulated sentence of the accused, meaning that criminal punishment of action shall not be imposed simultaneously. In the science of criminal law, a judge shall not impose a prison sentence that exceeds the maximum limit established by law. The judge can only decide the most severe punishment equal to the amount of imprisonment as set out in the relevant regulations. For the children's case, in Law no. 3 of 1997 has stipulated that the maximum limit of jail sentences for children is set lower than the criminal penalty against adults.If the naughty boy as referred to in Article 1 subarticle 2 letter a, hasn't reached the age of 12 (twelve) years, he commits a crime that is not threatened with death or is not subject to life-long penalty, then the child is imposed one of the actions as meant in Article 24: This provision applies only to a defendant of a child aged 12 (twelve) years, to an age of 18 (eighteen) years who has not committed a criminal offense punishable by death penalty or life imprisonment, such as a criminal offense, or extortion, the maximum imposed penalty is half the criminal penalty stipulated by the articles.A child committing a criminal offense under death penalty or life imprisonment when he is between 12 (twelve) years old and up to 18 (eighteen) years old, the judge can only impose a maximum imprisonment of 10 (ten) years. For example, the defendant committed a criminal act of premeditated murder. For a defendant aged 8 (eight) years up to before the age of 12 (twelve) years whose criminal offenses are threatened with capital punishment or life imprisonment, the judge can only impose penalties in the 
form of submitting to the state for education, coaching and vocational training .For the case of a child, the conditional penalty has been self-regulated in Article 29 of the Juvenile Court Law: The Judge may be subject to conditional imprisonment if the imprisonment is 2 (two) years imprisonment. A maximum of 2 (two) years is not the magnitude of criminal threats from a provision of the Law which is for the child, but the maximum sentence imposed by a special judge for a conditional penalty. In the court's decision on the conditional penalty, the Law requires that the judge determine two conditions: (1) The general requirement that a naughty child will not commit another criminal offense during a conditional period. If a crime is committed again, then the provision that it is mandatory to undergo the criminal law after there is an order from the judge, and (2) A special requirement is the determination of the attitude to perform or not to do certain matters specified in the judge's decision with due regard to the freedom of the child. What is meant by criminal penalty of supervision is a special punishment imposed on the child, namely the supervision made by the prosecutor against the child's behavior in daily life in the child's home, and the guidance provided by the correctional supervisor. The punishment by the judge in the form of the defendant's act is left to the state, then the naughty boy is subsequently placed in a child prison, the position of the convicted person as a child of the state. After being admitted to a Child Correctional Institution, the fate of the child is not left alone, but the head of the relevant institution should pay attention to the child's personally.

\section{RESEARCH METHODOLOGY}

This research was statutory approach, and case approach method. The purpose of this study is to find out "How the legal analysis of sentencing by judges in prosecuting murder committed by minors in the court.

\section{Basic Punishment}

\section{DISCUSSION}

The Basic Judgment of Judge Sentence in Judging Criminal Acts and Severe Persecution by Minors, Judgment Considerations Based on the facts revealed in the court has been proven to violate Article 340 of the Criminal Code and Article 351 (2):Whosoever element: whosoever in this element is the subject of: individuals, communities, groups allied together, or legal entities that first planned to eliminate the lives of others for personal and certain interests. Whereas against the defendant who has been brought before the court he / she has been able to answer all questions well and capable of acting in law and can be held legally accountable for his actions and there is no foundation for forgiving or justifying elements.Elements perform planning plans and threats of violence or maltreatment. Referred to as "making plans and threats of violence, or persecution" in accordance with the facts revealed in the hearing are related to the statements of witnesses and statements of the accused. Thus, these elements have been satisfied and proven legitimate and convincing according to the law.The grounds of the judges' considerations against the defendant include: That the defendant has violated the Criminal Code Article 340 and Article 351 paragraph (2) stateing: "Every person who commits a crime to eliminate the life of another person who first planned, either alone or group which resulted in severe injury, such person is duly convicted for 8 (eight) years, or a fine of up to Rp. 1,000,000 - (one thousand rupiah) ". That the defendant has committed acts of violence against the child of the Criminal Code Article 351 yat (2) about the persecution. Based on the analysis through KUHP Section 340 and Article 351 (2) concerning Planning investigated from judges' considerations, if it is related to Law no. 3 of 1997 on the Process of Procedures for Juvenile Justice and Child Protection Act no. 23 of 2002, it can be concluded that "the determination of the verdict is less precise, considering the defendant in which his age is still a teenager or younger, it needs better guidance and education in order to uphold the rights of children in Indonesia".

\section{CONCLUSION}

The conclusion of the research is that the criminal act of planning and severe maltreatment committed by the 16 -yearold child is one of the serious crimes, resulting in the death of the victim. In the demand of the Public Prosecutor in accordance with Article 340 and Article 351 (2) of the Criminal Code with the threat of imprisonment for a maximum of 10 (ten) years. Judges in prosecuting the case punishment of children in the ruling must be based on Law no. 3 of 1997 in Article 26 referred to Article 1 sub-article 2 letter a, shall be a maximum of a half year. Through some consideration, because considering the age of the defendant is still 16 (sixteen) years old and has never committed a previous criminal act, finally the Panel of Judges sentenced to 8 (eight) years imprisonment to the defendant. The judge's decision is appropriate that it has been based on the justice and wisdom, in order for rights to work properly. The judge should examine the background of life as well as the mental and psychological state of a child in the judicial and court proceedings and in its punishment. 


\section{REFERENCES}

[1] Adami, C. (2004). Kejahatan Terhadap Tubuhdan Nyawa. Jakarta: Rajawali Pers.

[2] Arifin. (2007). Pendidikan Anak Berkonflikdengan Hukum. Bandung: Alfabeta.

[3] Bonger, W.A. (1982). Pengantar Tentang Kriminologi. Indonesia, : Pembangunan

[4] Ghalia,B. W. (2000). Pidanadan Pemidanaan.Jakarta: RinekaCipta.

[5] Moelajatno.(2002).Azas-azas Hukum Pidana. Jakarta: RinekaCipta.

[6] Prints, D. (2003). Hukum Anak Indonesia. Bandung : Citra Aditya bakti,

[7] Sudarsono.(1991). KenakalanRemaja. Jakarta. : RinekaCipta.

[8] Soesilo, R. (2007). Kitab Undang-Undang Hukum Pidanadan Komentar-komentarnya. Bogor : Polite

[9] Wagiati, S. (2005). HukumPidanaAnak. Bandung: RefikaAditama. 